\title{
Preparing Students for a Bright Outlook: Survey of the Preparation of High School Counselors for Advising on Technician Careers
}

\author{
Sarah L. Ferguson ${ }^{\mathrm{a}}$, Benita Kluttz-Drye ${ }^{\mathrm{a}}$, Katrina A. Hovey ${ }^{\mathrm{b}}$

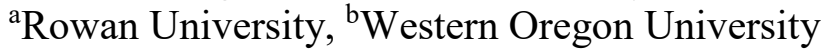

\begin{abstract}
This paper details a survey study of high school counselors' awareness of and comfort with advising students in technician/technologist careers. The survey focused on careers designated as Bright Outlook by the US Department of Labor to explore familiarity with these careers, the effectiveness of the current career advising process, and recommendations on additional support or resources. Results indicate participants were more familiar with technician/technologist careers in health and medicine than those in engineering or other areas of science. Counselors acknowledged the importance of familiarity with a career in the career advising process, but communicate a number of challenges they face in meeting this need. The participants provide specific recommendations for additional supports, and future research in this area is recommended.
\end{abstract}

Keywords: advanced technical careers, STEM technician and technologist, career advising, high school counselors

Science, technology, engineering, and mathematics (STEM) careers continue to receive increased focus in education due to decades-long initiatives aimed at increasing skills and expertise in the United States in STEM areas (Falco, 2016; Herr, 2013). Identifying workers for the STEM workforce is at a critical level (Shillingford, Oh, \& Finnell, 2018; Staffing Industry, 2018). Moreover, legislators are concerned that the lack of prepared STEM workers will cause the U.S. to be less competitive globally (Shillingford, Oh, \& Finnell, 2018). It is essential that students are appropriately advised in STEM career pathways to prepare them for global competition and citizenship (Byars-Winston, 2014). There is a need for further intervention specifically in the STEM career advising process to address the demand and shortfall of skilled workers available throughout the United States (Byars-Winston, 2014; Shillingford, Oh, \& Finnell, 2018; Wang \& Degol, 2013). It is projected that by 2028, 3.5 million workers will be needed for STEM careers but only approximately 1.1 million will be available creating a shortage of nearly 2.4 million STEM workers in the U.S. (Giffi et al., 2018).

(i) $(9)$ Creative Commons CC-BY-NC-ND: This article is distributed under the terms of the Creative Commons Attribution 4.0 License (http://creativecommons.org/licenses/by/4.0/) which allows others to download your works and share them with others as long as they credit you, but they can't change them in any way or use them commercially. 
Concerns have been raised about the lack of awareness by career advising professionals on the various STEM careers, pathways, and opportunities (Aschbacher, Li, \& Roth, 2010; Byars-Winston, 2014). Additionally, STEM technician and technologist careers have been specifically highlighted in recent reports by the National Academies of Engineering (NAE, 2016) and by Deloitte Insight (Giffi et al., 2018) highlighting a widening gap in available workers, impact of the shortage, difficulties with recruiting, and staffing for related education programs. Awareness of these career fields was identified as one possible source of continued low enrollment and employment numbers, despite the increasing workforce need for trained STEM technicians and technologists (Hull, Bolen, Illich, \& Glover, 2012; NAE, 2016).

Career advising plays a unique and potentially underutilized role in the career development process for students, and career advising professionals have the potential to impact key issues in STEM careers such as increasing diversity and access for underrepresented groups (Brown et al., 2003; Byars-Winston, 2014; Perna, RowanKenyon, Thomas, Bell, Anderson, \& Li, 2008; Shillingford, Oh, \& Fennell, 2018). School counselors have the potential to influence student career decision making with guidance around both academic courses of study and career exploration (Brown et al., 2003; ByarsWinston, 2014; Perna et al., 2008; Shillingford, Oh, \& Fennell, 2018). Positive effects of career advising have been supported repeatedly in the research literature (Brown et al., 2003; Milot-Lapointe, Savard, \& Le Corff, 2018; Perdrix, Stauffer, Masdonati, Massoudi, \& Rossier, 2012; Whiston, Tai, Rahardja, \& Eder, 2011). However, in general, school counselors face significant challenges in performing their duties, which includes increased demands of their time and expanded responsibilities beyond career advising (Falco, 2016; Schmidt, Hardinge, \& Rokutani, 2012; Whiston et al., 2011). Therefore, the present study is designed to explore the awareness by high school career advising counselors about STEM technician and technologist careers as compared to other technician and technologist careers to provide empirical support for these claims.

Prior research has advocated for increasing school counselors' awareness and expertise in STEM fields to increase their ability to support students in academic and career decisions (Byars-Winston, 2014; Falco, 2016; Schmidt et al., 2012; Shillingford, Oh, \& Fennell, 2018). The more aware school counselors are of the potential career opportunities in STEM fields, the better they may be able to advise their students in academic and career planning. Additionally, a prior study suggested counselors may be a source of both negative and positive support for STEM careers, depending on counselor knowledge and perspectives (Aschbacher et al., 2010; Shillingford, Oh, \& Fennell, 2018). However, where prior work has tended to focus on STEM careers broadly, the present study seeks to focus specifically on technician and technologist careers. Additionally, with the increasing responsibilities assigned to school counselors, it can be argued that expecting school counselors to know specifics of technician and technologist career fields may be unreasonable. To this end, the present study seeks to survey school counselors themselves to hear their perspective on their awareness of technician and technologist careers, and what impact they believe awareness of a career has on their ability to advise students. 


\section{Technician and Technologist Careers}

Technician and technologist careers are a subset of STEM careers focused on advanced technical skill positions in industries that support or create the products and projects developed through technology by engineers, scientists, and other professionals (Giffi et al., 2018; NSF, 2018; SUNY Canton, 2017). The National Science Foundation (NSF) funding program focused on advanced technical education identifies the following career fields as examples of STEM technician/technologist fields: advanced manufacturing technologies, agricultural and biotechnologies, energy and environmental technologies, engineering technologies, information technologies, micro- and nano-technologies, security technologies, and geospatial technologies (Giffi et al., 2018; NSF, 2018).

Technician and technologist careers typically require less formal training than more advanced STEM professional careers. For instance, an electrical engineer professional career typically requires $4+$ years of college education with a minimum qualification of a Bachelor's degree, while an electrical engineering technician typically requires 2 years of college education with a minimum qualification of a post-secondary certificate or Associates degree (CUNY, 2017; National Center for O*NET Development, n.d.). Many technician and technologist careers also offer individuals above-average salaries according to the US Census Bureau (2017), and a number of these career fields are designated as Bright Outlook by the US Department of Labor O*NET web service (National Center for O*NET Development, n.d.). Careers are considered Bright Outlook when they are projected to grow rapidly in the coming years and/or they are expected to have a large number of available positions. Additionally, Hull et al. (2012) reported advanced technology careers as one of the fastest growing segments within the workforce, with growth expectancy of approximately $14 \%$ over other jobs within the United States.

Research has shown a lack of awareness of technician and technologist careers (Hull et al., 2012; NAE, 2016). These careers are often overlooked in the career development literature (NAE, 2016). One possible reason for this oversight may be the perception of technician and technologist careers as less prestigious and therefore less desirable than other STEM fields. Technical and technologist careers are often connected to vocational education programs and may be susceptible to some social stereotypes associated with these careers (Fletcher \& Tyson, 2017; Herr, 2013). Modern technological innovations and increasing demand for technical skills in many vocational career fields has historically changed the perceptions of these careers (Fletcher \& Tyson, 2017; Herr, 2013). However, STEM technician and technologist careers specifically still receive less attention in STEM research and may be perceived as less prestigious when compared to other STEM careers (Binder, Davis, \& Bloom, 2016; Gottfredson, 2005; Herr, 2013; NAE, 2016; Sodano \& Tracey, 2008). It can be argued, for example, that a computer user support specialist would be rated as less prestigious than a computer scientist (Gottfredson, 2005; Sodano \& Tracey, 2008). Increasing awareness of and knowledge about technician and technologist careers and their pathways could potentially help overcome misunderstandings about these fields, and ultimately increase interest in these fields (NAE, 2016). 


\section{Theoretical Framework}

Career counseling, as an area of study, is uniquely positioned between two fields with unique theoretical frameworks: school counseling, with a theoretical focus on the process of counseling, and career development from the field of psychology, which is typically focused on internal processes and decision making for individuals. No theory from either side appears to clearly represent the external role of counselors in the internal process of career development, though more complex career development theories have spaces where this role can be inferred. For the present study, the choice was made to use Social Cognitive Career Theory (SCCT) as the primary theoretical lens for understanding (Brown \& Lent, 1996; Lent, Brown, \& Hackett, 2002). SCCT models career choice behaviors through a causal framework with person inputs and background contextual affordances theoretically impacting access to and benefit from learning experiences, which then theoretically impacts personal self-efficacy beliefs and outcome expectations, that then impacts career interests, career goals, and finally career choice actions (Brown \& Lent, 1996; Lent et al., 2002; Lent, 2013). Additionally, external contextual influences are understood to function as either supports or barriers to the internal process and can include social expectations, family support, mentoring, etc. (Brown \& Lent, 1996; Lent et al., 2002). Prior research has identified SCCT as particularly helpful in providing understanding to first-generation students and those facing unique life and career obstacles in making career decisions, as it models more aspects of the individual and relationships to career choice behaviors than other career development theories (Brown \& Lent, 1996; Lent, 2013; Olson, 2014).

Career advising for high school students can be inferred to be positioned in this process in two ways. First, we argue that school counselors providing career advising in high school settings is most closely connected with the SCCT component of learning experiences, which then has a direct impact on self-efficacy beliefs and outcome expectations for the student, and ultimately will impact interests and career choice goals (Brown \& Lent, 1996; Lent et al., 2002; Lent, 2013). Second, we argue that career advising may also be an external contextual influence, particularly for advising that takes place outside of the learning environment. This component is less clearly defined at this time and is not the primary focus of the current study, but could be an area of focus in future research. Therefore, for this study, the role of career advising in SCCT is specifically understood as assisting students in discovering career opportunities that align with their interests and in which they feel they can be successful, thereby increasing their self-efficacy and outcome expectations in relation to specific career options (Lent et al., 2002; Lent, 2013; Olson, 2014).

This theoretical framework can also provide justification for the focus on school counselors' knowledge of technician and technologist careers. In the same way that learning experiences increase self-efficacy and outcome expectations for students, the present study posits that increased counselor knowledge of careers will theoretically be associated with increased self-efficacy towards advising students about these careers and increased outcome expectations for their professional practice (Bandura, 1986; Brown \& Lent, 1996; Lent et al., 2002; Lent, 2013). Thus, SCCT is used in the present study to provide justification for the focus on technician/technologist career knowledge of 
participating school counselors, and to add theoretical understanding to the potential impact of school counselor knowledge of student career decision-making outcomes.

\section{Purpose}

The purpose of this research study is to examine high school counselors' current understanding, awareness, and preparation to advise students about STEM advanced technology career options. Specifically, this study examines how familiar school counselors are with Bright Outlook technician careers, explores the current career advising processes in high schools, reviews resources commonly used by school counselors when advising students about advanced technology careers with which counselors are unfamiliar, and identifies additional resources or supports that are needed to aid and inform counselors in their advising efforts. Hence, this study seeks to inform future interventions, programs, and practices of high school counselors in high technology careers fields.

The research questions driving this study are:

1. How familiar are current high school counselors involved in career advising with Bright Outlook technician/technologist careers?

a. Are there significant differences between familiarity with engineering/computer science technician/technologist careers and life science/health technician/technologist careers?

2. What impact do career counselors feel familiarity with a career has on their ability to advise students about that career?

3. What current processes are career counselors using to advise students about technician/technologist careers, particularly ones with which they are not familiar?

a. What existing resources do counselors use in career advising, particularly for careers with which they are not personally familiar?

4. What recommendations do counselors have for additional supports or resources that could be provided for their career advising work with technician/technologist careers?

Since this is an exploratory study, the researchers have few specific hypotheses identified at the onset. For research question one, we hypothesize the survey participants will be more familiar with life science/health technician/technologist careers than they are with engineering/computer science technician/technologist careers, due to increased exposure to life science and health careers in popular media and the closer connection between counseling and these fields. There are no prior hypotheses identified for research questions two through four.

\section{Methods}

This study was designed as an explanatory concurrent mixed-methods survey (Creswell \& Plano Clark, 2011; Hanson, Creswell, Plano Clark, Petska, \& Creswell, 2005). This specific method allowed the researchers to concurrently analyze both the quantitative and 
qualitative components of the survey to answer the research questions (Creswell \& Plano Clark, 2011; Hanson et al., 2005). This study is intended as a pilot study to describe current practice and perceptions, better equip counselors for advisement in these areas, and influence future counseling practices.

Participants were recruited from across the country from counselors providing careeradvising services in high school settings. There were no limitations placed on the location of the high schools and no limitations for participation were set based on gender, racial/ethnic identity, age, etc. However, counselors were required to currently provide career advisement services in their high school settings, so any counselors who may have worked in this area in the past but who had left these positions were not included. Invitations to participate in the study were sent out through the America School Counselors Association (ASCA) online member board, through professional and social media networks, and through publicly available email addresses directly to school counselors, with permission from IRB and the related professional associations. Informed consent was obtained from respondents prior to survey access and the survey was completed anonymously.

Data Collection. This survey study was conducted completely online through the Qualtrics survey system, and the researcher-created questionnaire was designed to take participants approximately five to ten minutes to complete (see Appendix A). The questionnaire included demographic questions such as how many years the participant has worked as a high school counselor, average number of high school students they work with, what type of high school they currently work at (public, private, charter, magnet), their age within a seven-year range, and their gender identity. Then, for the first two research questions, a list of 35 technician or technologist careers was provided, and respondents were asked to rate their familiarity with each career on a five-point Likert scale (Extremely Familiar to Not Familiar At All). These careers were selected for inclusion in the present study based on the O*NET database of technician and technologist careers considered Bright Outlook careers. All careers that fit this categorization were included, with a total of 17 falling in STEM fields and 18 falling in life science/health fields.

An additional question was asked regarding the perceived impact of familiarity with a career on ability to advise students about that career, with the following response options: a great deal, a lot, a moderate amount, a little, or none at all. To address research question three, an open-ended question was asked regarding the steps the participant takes and the resources they use when advising students about careers they as a school counselor are not familiar with. Finally, for research question four, an open-ended question was asked to solicit suggestions for additional support and/or resources for career advising professionals engaged in this work. No financial compensation, goods, or services were provided to any participant.

Analysis for research questions one and two are primarily focused on descriptive statistics looking at frequencies of responses to the ranked items. A chi-square analysis was used to specifically test the hypothesis that counselor participants would be more familiar 
Table 1. Summary Table of Familiarity with Select Technician/Technologist Career Fields

\begin{tabular}{lccccc}
\hline \multicolumn{1}{c}{ Technician Career Field } & $\begin{array}{c}\text { Extremely } \\
\text { Familiar }\end{array}$ & $\begin{array}{c}\text { Very } \\
\text { Familiar }\end{array}$ & $\begin{array}{c}\text { Moderately } \\
\text { Familiar }\end{array}$ & $\begin{array}{c}\text { Slightly } \\
\text { Familiar }\end{array}$ & $\begin{array}{c}\text { Not At All } \\
\text { Familiar }\end{array}$ \\
\hline Athletic Trainer & $\mathbf{4 0 \%}$ & $\mathbf{4 0 \%}$ & $12.5 \%$ & $7.5 \%$ & $0 \%$ \\
Dental Hygienist & $\mathbf{4 0 \%}$ & $37.5 \%$ & $17.5 \%$ & $2.5 \%$ & $2.5 \%$ \\
Emergency Medical & $25 \%$ & $\mathbf{4 5 \%}$ & $25 \%$ & $0 \%$ & $5 \%$ \\
Technician/Paramedic & & & & \\
Licensed & $25 \%$ & $27.5 \%$ & $\mathbf{3 5 \%}$ & $2.5 \%$ & $10 \%$ \\
Practical/Licensed & & & & \\
Vocational Nurse & $23 \%$ & $23 \%$ & $\mathbf{3 8 . 5 \%}$ & $10.3 \%$ & $5 \%$ \\
Midwife & $0 \%$ & $2.5 \%$ & $17.5 \%$ & $20 \%$ & $\mathbf{6 0 \%}$ \\
\hline Fuel Cell & $0 \%$ & $0 \%$ & $10 \%$ & $27.5 \%$ & $\mathbf{6 2 . 5 \%}$ \\
Remote Sensing & $0 \%$ & $5 \%$ & $2.5 \%$ & $25 \%$ & $\mathbf{6 7 . 5 \%}$ \\
Photonics & $0 \%$ & $0 \%$ & $5 \%$ & $12.5 \%$ & $\mathbf{8 2 . 5 \%}$ \\
Non-Destructive Testing & & & & $5 \%$
\end{tabular}

Note. Careers above the table break are health and life science focused, careers below the table break are engineering and science focused. The rating category most frequently indicated for each career is marked in bold.

with life science/health technician/technologist careers than they were with engineering/computer science technician/technologist careers. Chi-square is the most appropriate measure of association here due to the categorical nature of the items on career familiarity.

Open-ended items related to research questions three and four were analyzed using thematic analysis (Braun \& Clarke, 2006). A team of three researchers independently coded participant responses to identify meaningful concepts. Then, the team met to compare the resulting codes and refine or clarify codes collaboratively. Next, the participants' responses were evaluated again with the new coding structure, and each researcher identified broad themes across the codes for the two qualitative research questions. Finally, these resulting themes were shared between the three researchers and solidified into three themes for research question three and two themes for research question four.

\section{Results}

A total of 48 survey responses were recorded with 40 responses containing complete responses on at least the quantitative study questions, resulting in a useable $n=40$. The small sample size should be noted here and the following results should be read as exploratory and foundational evidence of this issue. Future research is needed to more clearly develop our understanding of school counselor's understanding of and role in career advising about technician/technologist careers. It is worth noting that although the sample size is small, study participants appear to be representative of school counselors across the United States. For example, participant demographics aligns with Winburn, Reysen, Suddeath, and Perryman (2018) in terms of gender, race/ethnicity, work setting, and number of students served. In this study, of responding participants, $80 \%$ identified as 
female and $20 \%$ as male. In terms of age, $23 \%$ of the participants were in the $25-34$ range, $40 \%$ in the $35-44$ range, $28 \%$ in the $45-54$ range, and $10 \%$ in the 55-64 range. Most of the participants (85\%) indicated they work in a public high school, with $5 \%$ each indicating a private high school and a charter high school, and $2.5 \%$ each indicating an alternative high school and a magnet high school. The respondents indicated they work with anywhere from 30 to 1,700 students, with an average across participants of $338.21(S D=245.53)$. In terms of experience, participants indicated they have worked in high school counseling for 1 to 30 years, with an average of 7.72 years $(S D=7.28)$.

Technician and Technologist Career Familiarity. In response to research question one regarding counselor familiarity with technician and technologist careers, Table 1 displays, on average, how familiar counselors were with careers. A chi-square analysis was conducted to test the hypothesis that counselor participants would be more familiar with medical technician and technologist careers than they were with engineering and STEM technician and technologist careers. Responses to the items on familiarity by career were separated into STEM careers versus life science/health careers, and the median responses across all careers in these two categories were calculated. Then, these two median variables were compared using chi-square, resulting in $\chi^{2} 28=44.27, p=$ 0.026 , Cramer's $V=0.526$. This indicates there is a statistically significant difference in median responses to familiarity items on life science and health technician and technologist careers as compared to STEM careers, with a large practical effect supported by the effect size Cramer's $V$. For the chi-squared test, the median was used instead of the mean due to the categorical nature of the responses on a 1-5 scale and instead of the mode to allow for more variance/variability.

As hypothesized, counselors appear to be more familiar with technician and technologist careers in health and life science fields than with those in engineering and other areas of science. However, counselor participants were generally less familiar with technician careers across the board, as no career was indicated as Extremely Familiar by more than $40 \%$ of the respondents. Additionally, technician careers arguably considered more common, such as Surgical Assistant and Veterinary Technician, were generally indicated as only Moderately Familiar to the respondents (35\% and 37.5\%, respectively).

Impact of Career Familiarity. For research question two on the impact of career familiarity on ability to advise students, participant responses were spread between A Lot (30\%), A Great Deal (30\%), and A Moderate Amount (32.5\%). No respondents indicated familiarity had No Impact on their advising ability and only $7.5 \%$ indicated it had A Little Impact. These responses appear to support the perceived importance of career familiarity for student career advising, though there is noteworthy variation in counselor beliefs regarding the role this knowledge might play.

Current Career Advising Resources. In response to research question three, participants identified a number of resources they currently use when advising students about a career with which they personally are not familiar. The use of online resources, collaborating with colleagues and other professionals, and reaching out to colleges or 
programs were the three major themes identified in the responses. The most common theme was the use of online resources, including Google Search, O*NET resources from the US Department of Labor, and college and career exploration programs and sites. A total of 35 respondents included some mention of online resources in their response to this question. For example, one counselor stated, "When a student inquires about a career path I am unfamiliar with I usually use Naviance [a common career exploration website used in schools] to search the occupation. If it has limited information I usually do a Google search and find related topics."

The second theme of collaborating with colleagues or other professionals, including business and industry professionals, was mentioned by 11 of the respondents. These responses included reaching out to people such as counselor colleagues, librarians, industry specialists, and local professionals. Finally, the third theme identified was reaching out to colleges or education programs, including trade and technical programs, for additional information about careers and college options. This was noted by six of the respondents in the present study. One participant stated that one of the activities that they have found beneficial is "...reaching [out to] local colleges that may have summer programs students can attend..."

Suggestions for Improvement. For research question four, respondents shared a number of suggestions for additional support and resources they could use to advise students on technician and technologist careers. One theme identified by nine respondents was the need for additional online resources and supports, specifically focused on high need or technical/technician careers covered in the present study. Some of the suggestions identified included videos of various careers, career updates provided by professional associations, updates and links for Bright Outlook careers for additional understanding and information, and email or social media updates. One participant explained,

For any given year, I would say I have spent no more than 10 hours a year with direct career advising. Most advising of this nature is handled indirectly in the form of advising students to explore the aforementioned career search websites or information posted on our social media site. With this being the case, easier to navigate career search websites and updates and our social media posts of these "Bright Outlook" careers could prove helpful.

The second theme identified in the responses to this item was exposure to careers including tours of industry sites and presentations by educational/technical programs. Responses in this theme included statements such as "I would love to visit Technical Colleges that offer training in these careers." and "Partnerships with local businesses and educational institutions [would be beneficial]". This theme was mentioned by seven of the respondents and was characterized by increasing exposure through industry and/or program-led workshops and tours. This was coded as slightly different from the third theme identified for this question, which focuses on additional education and/or professional development opportunities. Suggestions for this included holding sessions at professional conferences for school counselors, and field studies for counselors focused on careers where there is a lack of familiarity. One respondent specifically suggested to "Have several 
Journal of Research in Technical Careers

career field workshops. Mandatory trainings/experiences in at least five of these careers every three years."

\section{Discussion}

With the increased attention given to STEM fields and technology in the United States, there is a need to increase the focus on college and career advising towards careers across the STEM areas (Byars-Winston, 2014; Hull et al., 2012; National Center for O*NET Development, n.d.). Technician and technologist careers can be ideal options for some students, and many of these careers are considered Bright Outlook careers by the US Department of Labor, but students need to know these opportunities exist before they can consider them as a possible career option (Hull et al., 2012; NAE, 2016). As supported in SCCT, career advising in high school is one area where information about these careers can be shared, but the results of the present study highlight the lack of awareness for school counselors around many of these careers (Aschbacher et al., 2010; Brown \& Lent, 1996; Lent, 2013; Lent et al., 2002). The findings in the present study provide a foundational exploration of this issue with currently practicing school counselors, and discussion is focused on what we can infer from these results currently. However, further research is needed to clarify and expand our understanding of this issue and the impact school counselor knowledge potentially has on students as they make career decisions.

From research question one, technician and technologist career fields in engineering especially appeared to be unfamiliar to participants in the present study, indicating there is a need for further support for career advisers in relation to these careers. These finding are in line with previous research about student awareness, further supporting the need for intervention to support career advising and exploration towards technician and technologist careers specifically (Hull et al., 2012; NAE, 2016). However, it should also be noted that technician and technologist careers outside of engineering fields were also largely unfamiliar to school counselors in the present study. This suggests that further training and resources are needed related to all technician and technologist fields, including those outside of engineering areas.

For research question two, participants supported the importance of career familiarity in the career advising process. This is generally in line with prior research that has suggested an increased focus to school counselor training and awareness of STEM careers (Aschbacher et al., 2010; Byars-Winston, 2014; Falco, 2016; Schmidt et al., 2012). However, they also acknowledged the limitations of their role and their inability to be familiar with all career options (Falco, 2016; Schmidt, Hardinge, \& Rokutani, 2012; Whiston et al., 2011). As one respondent in the present study stated, "School counselors cannot realistically be familiar with every single career in existence..." but more can be done to support their efforts in key career areas such as technician and technologist career pathways.

For research questions three and four, participants shared specific examples of resources they currently use and supports they feel could benefit them in providing guidance to students about technician and technologist careers. From both questions, online resources, personal connections, and increased education for school counselors came 
through as predominant themes. Prior research has suggested additional education and training for school counselors related to STEM careers, and this is supported in the present study (Aschbacher et al., 2010; Byars-Winston, 2014; Falco, 2016; Schmidt et al., 2012). However, throughout the responses in the present study there is evidence of lack of knowledge on how to address this problem. Responses suggesting additional training, professional development, and online resources speak to participants' search for assistance in supporting their students in these areas. School counselors need support in providing the career-specific guidance suggested in the literature and in the present study. Based on the results here, school counselors do not appear to have all of the resources they need to do this work effectively (Perna et al., 2008; Whiston et al., 2011).

Limitations. The present study is limited by the relatively small sample size $(n=40)$ and cannot be considered representative of all high school counselors in the United States. As a result, conclusions and implications from this study should be considered exploratory and general until future research is conducted to support or provide alternative explanations for this study. Additionally, counselor knowledge of careers surveyed in this study may be impacted by other factors such as the age of the career, regional differences, personal experiences or connections of the counselor, and other factors not currently accounted for in the present study. Finally, the self-report survey used in the present study is limited in depth of explanation from the participants and future research may benefit from additional data collection practices such as focus groups or interviews.

\section{Implications and Future Research}

As mentioned previously, the current study is a foundational exploration of high school counselor knowledge and advising practice about technician/technologist careers. Future research should first replicate this study with larger samples of school counselors to evaluate the validity of these results across contexts. Additionally, further research is needed in response to the suggestions provided by counselors in the present study, such as how counselors can better connect with industry experts and secondary education programs for STEM technician/technologist careers. In response to the concerns about time in the school counseling profession, future research should also focus on ways to increase effectiveness in creating and maintaining connections with education and industry partners and identify ways to accomplish this within their time constraints. Future work may also look at on online resources specific to technician and technologist careers for ways to provide school counselors with informative, timely, and easily accessible resources for themselves and their students. Some work has already been conducted in this area, particularly in connection to grant funded studies and research centers, such as those funded through the National Science Foundation's Advanced Technological Education grant program (Frisbee, Belcher, \& Sanders, 2000; NSF, 2018; Orser, Riding, \& Stanley, 2012). Expansion of these models and resources specifically focused on school counselors and high school students would fit the suggestions of the participants in the present study. 
Journal of Research in Technical Careers

\section{References}

Aschbacher, P. R., Li, E., \& Roth, E. J. (2010). Is science me? High school students' identities, participation and aspirations in science, engineering, and medicine. Journal of Research in Science Teaching, 47, 564-582. https://doi.org/10.1002/tea.20353

Bandura, A. (1986). Social foundations of thought and action: A social cognitive theory. Englewood Cliffs, NJ: Prentice Hall.

Binder, A. J., Davis, D. B., \& Bloom, N. (2016). Career funneling: How elite students learn to define and desire " prestigious" jobs. Sociology of Education, 89(1), 20-39. https://doi.org/10.1177/0038040715610883

Braun, V., \& Clarke, V. (2006). Using thematic analysis in psychology. Qualitative Research in Psychology, 3(2), 77-101.

Brown, S. D., Krane, N. E. R., Brecheisen, J., Castelino, P., Budisin, I., Miller, M., \& Edens, L. (2003). Critical ingredients of career choice interventions: More analyses and new hypotheses. Journal of Vocational Behavior, 62, 411-428.

Brown, S. D., \& Lent, R. W. (1996). A social cognitive framework for career choice counseling. The Career Development Quarterly, 44, 354-366.

Byars-Winston, A. (2014). Toward a framework for multicultural STEM-focused career interventions. The Career Development Quarterly, 62, 340-357.

Falco, L. D. (2017). The school counselor and STEM career development. Journal of Career Development, 44, 359-374. https://doi.org/10.1177/0894845316656445

Fletcher, E. C., Jr., \& Tyson, W. (2017). Bridging technical skills gaps between high school students and local employers. Journal of Research in Technical Careers, 1, 20-31. https://doi.org/10.9741/2578-2118.1001

Frisbee, R., Belcher, G., \& Sanders, R. (2000). Recruitment techniques that influence students to attend four-year automotive programs. Journal of Vocational Education Research, 25(2), 104-125.

Giffi, C., Wellener, P., Dollar, B., Manolian, H. A., Monck, L., and Moutray, C. (2018). The jobs are here but where are the people? Deloitte Insight, $1-8$.

Gottfredson, L. S. (2005). Using Gottfredson's theory of circumscription and compromise in career guidance and counseling. Career Development and Counseling: Putting Theory and Research to Work, 71-100. Retrieved from http://www.udel.edu/educ/gottfredson/reprints/2004theory.pdf

Hanson, W. E., Creswell, J. W., Clark, V. L. P., Petska, K. S., \& Creswell, J. D. (2005). Mixed methods research designs in counseling psychology. Journal of Counseling Psychology, 52, 224-235. https://doi.org/10.1037/0022-0167.52.2.224

Herr, E. L. (2013). Trends in the history of vocational guidance. The Career Development Quarterly, 61, 277-282. https://doi.org/10.1002/j.2161-0045.2013.00056.x

Hull, D. M., Bolen, J. A., Illich, P. A., \& Glover, R. J. (2012). Industry demand for community college graduates in advanced technological education: Estimates from a national employer survey in optics and photonics technology. International Journal of Business, Humanities and Technology, 2, 99-108.

Lent, R. W. (2013). Career-life preparedness: Revisiting career planning and adjustment in the new workplace. The Career Development Quarterly, 61, 2-14.

Lent, R. W., Brown, S. D., \& Hackett, G. (2002). Social cognitive career theory. Career Choice and Development, 4, 255-311. 
National Academy of Engineering. (2016). Engineering technology education in the United States. Washington, DC: National Academies Press. https://doi.org/10.17226/23402

National Center for O*NET Development. (n.d.). Technologists and technicians STEM occupations. $O * N E T$ OnLine. Retrieved September 19, 2018, from https://www.onetonline.org/find/stem?t=2

National Science Foundation. (2018). Advanced technological education program solicitation. Retrieved from: https://www.nsf.gov/pubs/2018/nsf18571/nsf18571.htm\#summary

Olson, J. S. (2014). Opportunities, obstacles, and options: first-generation college graduates and social cognitive career theory. Journal of Career Development, 41, 199-217.

Orser, B., Riding, A., \& Stanley, J. (2012). Perceived career challenges and response strategies of women in the advanced technology sector. Entrepreneurship \& Regional Development, 24(12), 73-93.

Perdrix, S., Stauffer, S., Masdonati, J., Massoudi, K., \& Rossier, J. (2012). Effectiveness of career counseling: A one-year follow-up. Journal of Vocational Behavior, 80, 565-578.

Perna, L. W., Rowan-Kenyon, H. T., Thomas, S. L., Bell, A., Anderson, R., \& Li, C. (2008). The role of college counseling in shaping college opportunity: Variations across high schools. The Review of Higher Education, 31(2), 131-159.

Schmidt, C. D., Hardinage, G. B., \& Rokutani, L. J. (2012). Expanding the school counselor repertoire through STEM-focused career development. The Career Development Quarterly, 60, 25-35.

Shillingford, M. A., Oh, S., \& Finnell, L. R. (2018). Promoting STEM career development among students and parents of color: Are school counselors leading the charge? Professional School Counseling, 21(1), 1-11.

Sodano, S. M., \& Tracey, T. J. (2008). Prestige in interest activity assessment. Journal of Vocational Behavior, 73, 310-317. https://doi.org/10.1016/j.jvb.2008.07.002

Staffing Industries Analysis. (2018). Shortage of STEM Workers At Crisis Level, Says 20\% In Survey. Retrieved from: https://www2.staffingindustry.com/site/Editorial/DailyNews/Shortage-of-STEM-workers-at-crisis-level-say-20-in-survey-47144

State University of New York. (2018). Who is a technician, technologist, or engineer? Retrieved from http://www.canton.edu/csoet/elec/technician.html

United States Census Bureau / American FactFinder. Earnings in the past 12 months. 2017 American community survey. U.S. Census Bureau's American Community Survey Office. Retrieved September 19, 2018, from https://factfinder.census.gov/faces/tableservices/jsf /pages/productview.xhtml?pid=ACS_17_1YR_S2001\&prodType=table

Wang, M. T., \& Degol, J. (2013). Motivational pathways to STEM career choices: Using expectancy-value perspective to understand individual and gender differences in STEM fields. Developmental Review, 33, 304-340.

Whiston, S. C., Tai, W. L., Rahardja, D., \& Eder, K. (2011). School counseling outcome: A metaanalytic examination of interventions. Journal of Counseling \& Development, 89(1), 37-55.

Winburn, A., Reysen, R., Suddeath, E., \& Perryman, M. (2018). Working beyond the bell: School counselors and workaholism tendencies. Professional School Counseling, 21(1), 1-8. https://doi.org/10.1177/2156759X18775137 


\section{Appendix A: Survey Instrument}

Full informed consent notice provided as required by university IRB. Following this, participants were asked the following questions:

Q1 To participate in this survey, you must be 18 years or older and currently work as a high school counselor providing career advising services.

O Yes, I am 18 years or older and work as a high school counselor advising students about careers (1)

O No, I am not 18 years or older AND/OR I do not work as a high school counselor advising students about careers (2)

Condition: No, I am not 18 years or ol... Is Selected. Skip To: End of Survey.

Q2 Completing this survey indicates that you are voluntarily giving consent to participate in the survey

O Yes, I consent to participate in the survey (1)

O No, I do not consent to participate in the survey (2)

Condition: No, I do not consent to par... Is Selected. Skip To: End of Survey.

Q3 The following is a list of technician/technologist careers from the O*NET Online database. Please indicate your familiarity with each of these occupations: 


\begin{tabular}{|c|c|c|c|c|c|}
\hline & $\begin{array}{l}\text { Extremely } \\
\text { familiar } \\
\text { (1) }\end{array}$ & $\begin{array}{c}\text { Very } \\
\text { familiar } \\
(2)\end{array}$ & $\begin{array}{l}\text { Moderately } \\
\text { familiar (3) }\end{array}$ & $\begin{array}{c}\text { Slightly } \\
\text { familiar } \\
(4)\end{array}$ & $\begin{array}{c}\text { Not } \\
\text { familiar } \\
\text { at all } \\
\text { (5) }\end{array}$ \\
\hline $\begin{array}{l}\text { Electrical/Electromechanical } \\
\text { Engineering Technologist (1) }\end{array}$ & O & O & $\mathrm{O}$ & $\mathrm{O}$ & O \\
\hline $\begin{array}{l}\text { Forensic Science Technician } \\
\text { (2) }\end{array}$ & O & O & O & O & $\mathrm{O}$ \\
\hline Fuel Cell Technician (3) & O & $\mathrm{O}$ & $\mathrm{O}$ & $\mathrm{O}$ & O \\
\hline $\begin{array}{c}\text { Veterinary } \\
\text { Technician/Technologist (4) }\end{array}$ & O & O & $\mathrm{O}$ & $\mathrm{O}$ & O \\
\hline $\begin{array}{l}\text { Industrial/Manufacturing } \\
\text { Technologist/Technician (5) }\end{array}$ & O & $\mathrm{O}$ & $\mathrm{O}$ & $\mathrm{O}$ & O \\
\hline $\begin{array}{c}\text { Surgical } \\
\text { Assistant/Technologist (6) }\end{array}$ & O & O & O & $\mathrm{O}$ & O \\
\hline $\begin{array}{l}\text { Mechanical Engineering } \\
\text { Technologist (7) }\end{array}$ & $\mathrm{O}$ & $\mathrm{O}$ & O & $\mathrm{O}$ & O \\
\hline Radiologic Technician (8) & ○ & ○ & ○ & ○ & O \\
\hline $\begin{array}{l}\text { Nanotechnology Engineering } \\
\text { Technician/Technologist (9) }\end{array}$ & O & O & O & O & O \\
\hline Orthotist and Prosthetist (10) & $\bigcirc$ & $\bigcirc$ & $\mathrm{O}$ & $\mathrm{O}$ & $\bigcirc$ \\
\hline $\begin{array}{l}\text { Non-Destructive Testing } \\
\text { Specialist (11) }\end{array}$ & O & $\mathrm{O}$ & $\mathrm{O}$ & $\mathrm{O}$ & O \\
\hline Dispensing Optician (12) & $\mathrm{O}$ & $\mathrm{O}$ & $\mathrm{O}$ & $\mathrm{O}$ & $\mathrm{O}$ \\
\hline Photonics Technician (13) & 0 & $\mathrm{O}$ & O & O & 0 \\
\hline $\begin{array}{c}\text { Ophthalmic Medical } \\
\text { Technician/Technologist (14) }\end{array}$ & $\mathrm{O}$ & $\mathrm{O}$ & O & $\mathrm{O}$ & O \\
\hline Robotics Technician (15) & $\mathrm{O}$ & ○ & ○ & ○ & $\bigcirc$ \\
\hline $\begin{array}{c}\text { Neurodiagnostic Technologist } \\
\text { (16) }\end{array}$ & $\mathrm{O}$ & O & $\mathrm{O}$ & $\mathrm{O}$ & O \\
\hline $\begin{array}{l}\text { Automotive Engineering } \\
\text { Technician (17) }\end{array}$ & $\mathrm{O}$ & O & O & $\mathrm{O}$ & O \\
\hline Midwife (18) & ○ & ○ & O & ○ & $\bigcirc$ \\
\hline $\begin{array}{l}\text { Precision Agriculture } \\
\text { Technician (19) }\end{array}$ & $\mathrm{O}$ & $\mathrm{O}$ & $\mathrm{O}$ & $\mathrm{O}$ & O \\
\hline $\begin{array}{l}\text { Medical Records and Health } \\
\text { Information Technician (20) }\end{array}$ & $\mathrm{O}$ & O & O & O & O \\
\hline Quality Control Analysts (21) & O & O & $\mathrm{O}$ & $\mathrm{O}$ & O \\
\hline
\end{tabular}




\begin{tabular}{|c|c|c|c|c|c|}
\hline $\begin{array}{c}\text { Medical and Clinical } \\
\text { Laboratory } \\
\text { Technician/Technologist (22) }\end{array}$ & $\bigcirc$ & $\mathrm{O}$ & $\mathrm{O}$ & $\mathrm{O}$ & $\mathrm{O}$ \\
\hline $\begin{array}{l}\text { Remote Sensing Technician } \\
\text { (23) }\end{array}$ & $\mathrm{O}$ & $\mathrm{O}$ & $\mathrm{O}$ & O & $\mathrm{O}$ \\
\hline $\begin{array}{l}\text { Licensed Practical/Licensed } \\
\text { Vocational Nurse (24) }\end{array}$ & 0 & 0 & $\mathrm{O}$ & O & $\mathrm{O}$ \\
\hline $\begin{array}{l}\text { Computer User Support } \\
\text { Specialist (25) }\end{array}$ & 0 & 0 & $\mathrm{O}$ & $\mathrm{O}$ & $\mathrm{O}$ \\
\hline $\begin{array}{l}\text { Histotechnologist and } \\
\text { Histologic Technician (26) }\end{array}$ & 0 & $\mathrm{O}$ & $\mathrm{O}$ & O & O \\
\hline $\begin{array}{c}\text { Cartographer and } \\
\text { Photogrammetrist (27) }\end{array}$ & 0 & $\mathrm{O}$ & $\mathrm{O}$ & $\mathrm{O}$ & $\mathrm{O}$ \\
\hline Hearing Aid Specialist (28) & 0 & $\mathrm{O}$ & $\mathrm{O}$ & $\mathrm{O}$ & O \\
\hline Athletic Trainer (29) & $\mathrm{O}$ & $\mathrm{O}$ & $\mathrm{O}$ & $\mathrm{O}$ & $\mathrm{O}$ \\
\hline Genetic Counselor (30) & $\mathrm{O}$ & $\mathrm{O}$ & $\mathrm{O}$ & O & O \\
\hline $\begin{array}{c}\text { Cardiovascular } \\
\text { Technologist/Technician (31) }\end{array}$ & 0 & $\mathrm{O}$ & $\mathrm{O}$ & O & $\mathrm{O}$ \\
\hline $\begin{array}{c}\text { Emergency Medical } \\
\text { Technician/Paramedic (32) }\end{array}$ & $\mathrm{O}$ & $\mathrm{O}$ & $\mathrm{O}$ & O & $\mathrm{O}$ \\
\hline $\begin{array}{c}\text { Cytogenetic } \\
\text { Technologist/Cytotechnologist } \\
\text { (33) }\end{array}$ & $\mathrm{O}$ & $\mathrm{O}$ & $\mathrm{O}$ & $\mathrm{O}$ & $\mathrm{O}$ \\
\hline $\begin{array}{l}\text { Diagnostic Medical } \\
\text { Sonographer (34) }\end{array}$ & O & $\mathrm{O}$ & $\mathrm{O}$ & $\mathrm{O}$ & $\mathrm{O}$ \\
\hline Dental Hygienist (35) & 0 & 0 & 0 & 0 & 0 \\
\hline
\end{tabular}

Q4 All of the careers on the previous screen are considered by the Department of Labor to be Bright Outlook careers, or occupations that "are expected to grow rapidly in the next several years, will have large numbers of job openings, or are new and emerging occupations." Considering this and your level of familiarity with these careers, how much of an impact do you feel familiarity with a career has on your ability to advise a student regarding that career?

O A great deal (1)

O A lot (2)

O A moderate amount (3)

O A little (4)

O None at all (5) 
Q5 When advising about careers that you are not personally familiar with, what steps do you usually take in advising students? Are there specific resources you typically use?

Q6 What suggestions do you have, if any, for what can be done to better support your work in advising students about technician careers, particularly if it is a career you are not familiar with?

Q7 How many years have you worked as a high school counselor?

Q8 Thinking about the high school you currently work at, what is the approximate student population at your school?

Small (less than 500 students) (1)

Medium (between 500 and 1,000 students) (2)

O Large (more than 1,000 students) (3)

Q9 What is your current age?

Under 18 (1)

O 18 - $24(2)$

○ $25-34(3)$

O $35-44(4)$

O $45-54(5)$

O $55-64(6)$

O $65-74(7)$

○ 75 - 84 (8)

O 85 or older (9)

Prefer not to say (10)

Q10 What gender do you identify with?

O Female (1)

O Male (2)

Non-binary/third gender (3)

Prefer to self describe (4)

O Prefer not to say (5) 